\title{
埼玉県「浮野の里」における湿地の変遷と 地域景観資源としての認識過程に関する研究
}

\author{
Study on the Resident's Cognitive Process of a Marsh as Local Landscape Resources \\ and Change of a Marsh in Ukiya no Sato, Saitama Prefecture.
}

\author{
大澤 啓志* 間野 明奈** \\ Satoshi OSAWA* Akina MANO**
}

\begin{abstract}
In this study, we traced the change of a marsh as a local resource in "Ukiya no sato". We considered the resident's cognitive process in the continuation of the rural landscape conservation activity undertaken by them. We identified 3 sites which had a marsh for about 70 years - from 1948 to the present day. These marshes had been an inefficient use of land for the local community as they yielded high food produce. This has resulted from the natural condition of over-humidity due to the poor drainage. On the other hand, residents have initiated conservation activities for these marsh landscapes as the spring water from the buried valley helps in the formation of a rare wetland plant community, turning the marsh into a natural monument. These marshes have now been transformed into local attractions. Iris ensata var. ensata and Euphorbia Adenochlora were viewed as a distinctive characteristic of these marshes. In our questionnaire survey, about $75 \%$ of the respondents recognized that the marsh landscape has been preserved by their activities for 20 years. Though they have done various trouble and hard work in landscape conservation work, about $87 \%$ of the respondents felt satisfied with their efforts. The results of a cross tabulation indicated that communication between the residents and pride in their hometown are the factors that affect participation in landscape conservation work. The residents continued landscape conservation work as they recognized that growing of $E$. Adenochlora involved traditional marsh management techniques such as open burning.

Keywords : Landscape Conservation Activity, Symbol of Natural Resources, Burn, Euphorbia Adenochlora, Buried Valley, Rewarding in Activity

キーワード：景観保全活動，自然資源のシンボル，野焼き，ノウルシ，埋没谷，活動のやりがい
\end{abstract}

1.はじめに

農村の景観保全活動において，住民が地域の価値を再 発見し地域アイデンティティーの醸成を得るために, 自 然資源（半自然的要素も含む）をシンボルに用いること は効果的である。例元ば棚田, 散居集落景観, ホ夕ル水 路, ため池・湧水地, トキ・コウノトリ等が良く知られ ている。その際, 二次的自然である農村景観の保全には 空間的な人為植生管理が不可欠となるが，二次的自然か ら得られる様々な生物資源材の経済性が低下しつつある 今日，それぞれの地域における人為管理の持続に対する インセンティブの確保が課題となる。

本研究では, かって萱材の採取地であった過湿地の土 地利用（ヨシ原）を，“地域を特徵付ける景観”という地 域景観資源に転換することで, 保全活動を継続している
埼玉県加須市「浮野の里」の事例に着目した。そこでは 景観保全のために地元住民団体「浮野の里・蔁の会」(以 下, 莘の会) がヨシ原の野焼き活動等を 20 年間継続して おり, 本事例を通じて保全活動の展開における地域景観 資源の価值の獲得プロセスを明らかにすることは意義あ るものと考元る。

ヨシ原の住民による利活用についての既往研究は, 例 えば北上川河口部や渡良瀬遊水地, 仏沼湿原といった主 として大正期以降の治水や干拓事業により新たに生じた 大規模なヨシ原での，ヨシ生産及びその後の火入れによ る景観保全活動の経緯や価值認識の変遷を報告したもの がある ${ }^{1-3)}$ 。一方，旧来から存在したヨシ原の利用・管理

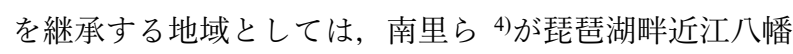
におけるヨシ原の分布や質, ヨシ生産の在り方の変化を 明らかにするなかで人とヨシ原の関係性の継続に正当性

\footnotetext{
*日本大学生物資源科学部 $* *$ 元日本大学大学院生物資源科学研究科

*College of Bioresource Sciences, Nihon University $\quad$ **(ex) Graduate School of Bioresource Sciences, Nihon University
} 


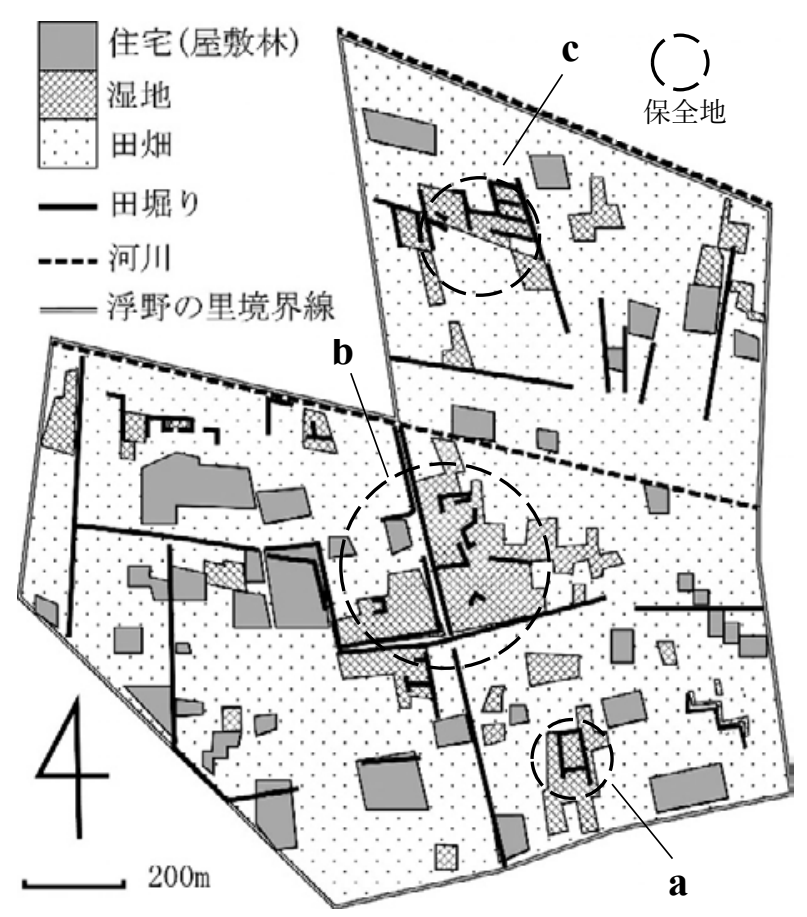

Fig.1「浮野の里」の土地利用状況と保全地の分布 Land use in Ukiya no Sato and distribution of conservation sites.

を認め, その維持・再生の重要性を指摘している。これ に対し曽根・近藤 5) は, 近年, 琵琶湖における水質浄化 作用等のヨシ原の環境的価值が見直され，大津市におけ る行政や地域住民等が主体となったヨシ刈りや火入れ活 動と萱材のイベント利用の展開を報告している。また, 寺林 のは津軽の岩木川下流部でのヨシ原における環境史 （地域社会と自然環境の相互作用の時系列的な把握）を 明らかにし, ヨシ生産の当事者性の成立過程, 利用・管 理の変容, 特に地域内での権益・非権益者間の火入れ管 理の受容意識の差について報告している。

これらに対し，本事例は必ずしも大規模ではないヨシ 原（数 ha 程度）において，住民活動が開始された当初か ら地域景観保全を主目的としており，経済性がほとんど 見込めない分，管理には湿地（ヨシ原）に対する住民の 意識面がより深く関わると考元られ，活動持続のインセ ンティブは異なる性質を持つと考元られる。以上より, 本研究は「浮野の里」における湿地の変遷を明らかにす るとともに，その景観保全活動に対する活動団体構成員 の意識, 特に地域景観資源に対する認識過程を把握する ことを目的とした。

\section{2. 対象地の概要及び調査方法}

加須市（人口約 11.4 万人：2018 年時点）は埼玉県の北 東部，都心から概衫 $50 \mathrm{~km}$ 圈に位置している。関東平野 のほぼ中央を流れる利根川中流域にあり，市全域が利根
川の運んだ土砂の堆積により形成された平坦地となって いる。農業が盛んで, 市域約 $133 \mathrm{~km}^{2}$ の $49 \%$ が田畑とし て利用されている（2018 年時点）。

「浮野の里」（125ha）は加須市北東部の北篠崎，多門 寺地区にまたがった地域である（Fig.1)。「武蔵野の面影」 を残す農村地域 7で，平地農業地域でありながらも田堀 りやヨシ原湿地，クヌギ並木，散居屋敷林といった独特 の田園風景が保たれ，1995 年に国土庁「水の郷百選」に 認定されている。1982 年から市により中心的な湿地が公 有地化されるとともに，その周緑部分も埼玉県「緑の卜 ラスト保全第 10 号地」に指定されている（両者を合わせ て以下, 保全地; Fig.1 : a c )。

対象地周辺は加須低地と呼ばれ, 古い台地地形が地下 に埋没しており, 埋没台地と呼ばれる特異な低地地形と なっている ${ }^{8)}$ 。約 2 万年前に海水面が低下した際に，そ れまでの海底が陸化して河川浸食により谷が生じ，縄文 海進時の海の堆積物やその後の河川堆積物の堆積そして 関東造盆地運動の沈降により，埋没谷（埋積谷）となっ たとされる ${ }^{8)}$ 。「浮谷」(後述) 付近は埋没谷の埋積物が 泥炭層で, 埋没谷から泠たい地下水が湧出して北方系の 特殊植物が生育（後述）している 8,9 )。このため過湿地と なり,かつては水田耕作には不適な所であったとされる。 しかし，幅 2〜3m，長さ $40 \cdot 50 \mathrm{~m} \sim 100 \mathrm{~m}$ に近い溝を縦 横に掘り上げた「掘上田」 ${ }^{8)}$ にり, 江戸時代には低湿地 にも水田が拓かれるようになった ${ }^{10)}$ 。午の掘り跡は「田 堀り」と呼ばれる幅のある水堀として, 現在も随所に残 っている。「浮野の里」には，これらの水田開拓の努力が なされながらも水田にできなかった過湿地がまとまって 存在している (後述)。その過湿地のヨシ原の最も規模の 大なものは「ちりじ野」（Fig.1：b）と呼ばれ，住民の景 観保全活動の実践の場となっている。現在は水田の耕作 放棄によるヨシ原等も多いが，明治初期に調查編纂され た『武蔵国郡村誌』11)には北篠崎村に約 0.9ha の芦萱野が 税地として記されており，税地すなわち農耕地とは異な る産業利用地としての湿地が一定規模存在していた。当 時の湿地維持の主な手法としては野焼きすなわち火入れ 管理が想定され 6，本対象地でも以前は「ちりじ野」等 の湿地で地区住民により個別に小規模な野焼きが行われ るとともに萱材を得ていた（地区内での利用）とされる 注1)。

調査は, まず現在の湿地の分布として, 2016 年の全域 踏査による確認を行った。次に過去の航空写真（1948・ $1960 \cdot 1975 \cdot 1986 \cdot 1998 \cdot 2009$ 年撮影 : 国土地理院発行 $)$ 及び第一軍管区地方 2 万分 1 迅速測図原図(迅速測図)』 12）（1880～1886 年作成）より，各時期の湿地の分布状況 の変遷を把握した。なお本研究では湿地として, 非耕作 
地で主に湿生の自然的・半自然的草地がまとまって存在 する場所を抽出対象としており, 航空写真では耕作放棄 地も含む湿生草地及び迅速測図では蘆・芦の凡例となっ ている薄い青色で着色された範囲とした。

次に,「浮野の里」の保全に向けた経緯を把握するため, 加須市環境政策課及び教育委員会への資料収集及びヒア リングを行った（2016 年春期に実施）。合わせて莘の会 会長注 2)に対しても活動経緯や会員の活動意識について ヒアリングを行った (2016 年 4 月, 9 月, 12 月の計 3 回, 各回対面形式で $0.5 \sim 1$ 時間実施)。さらに, 葦の会会員 に対し, 活動意識や地域の認識等についてアンケート調 査を行った。質問項目は, 属性（男女, 齢年代, 当地区 での居住期間）の他，以下のとおりである。

・「浮野の里」の魅力や美しさをつくりだしているものは 何か（用意した項目からの選択式）

・「浮野の里」をどの程度利用しているか（4段階の順序 尺度水準)

・「葦の会」の活動にどのくらい参加しているか（過去数 回／年 1 回程度／年数回程度／おおよそ毎回）

・「葦の会」の活動に参加した際の「やりがい」や「楽し み」はあるか（ある／まあまあある/ない）

・上記の問いで「ある」と回答した人に対し，具体的に 「やりがい」や「楽しみ」は何か（自由記述）

・「葦の会」のこれまでの地域への貢献度合いについて自 身はどう思うかとして, (1)「浮野の里」の景観が維持・ 保全できている，(2)来訪者が増えることによって地 域の良さを再認識し地域への誇りが強まった, (3)活 動や寄り合いを通じて住民間の連携が強まった，の 3 つを提示（いずれも5 段階の順序尺度水準）
・現在,「浮野の里」の保全や活用についてどのような問 題点があるか, またその問題点はどうすれば解決で きるか（自由記述）

・「莘の会」の野焼き活動によって「ちりじ野」等のヨシ 原で野生動植物の暮らす環境が守られているが, そ の代表的な次の 2 種を知っているかとして, (1)ノウ ルシ (Euphorbia Adenochlora) 注3)及び(2)カヤネズミ

(Micromys minutus) を提示（見たことがある/見た ことはないが知っている/知らない)

アンケートは，2017 年 2 月〜6 月の葦の会の会合や活 動時に参加会員へ計 100 枚の配布を行った。なお, 本地 区では, 2001 年にも住民意識等についてのアンケート調 査が財) 日本ナショナルトラストにより行われており(全 310 世帯に 930 票配布, 回収率 66.2\%)7), 重複あるいは 関連する質問項目については 2 時期（2001 年／2017 年） で比較した。

\section{3. 結果}

\section{1 「浮野の里」における湿地の変遷}

迅速測図及び我が国で入手可能な 1940 年代後半以降 の航空写真そして現況の調査を基に, 湿地の分布状況の 変遷を Fig.2 に示した。航空写真では 1986 年までは湿地 は概ね同じ範囲に止まっていたが，それ以降になると隣 接水田や他の水田が休耕湿地に転換し始めるのが確認さ れ，特に 2009 年からその量が顕著となっていた。また， 少なくとも戦後直ぐ（1948 年）より現在までの約 70 年 間, ヨシ原等の湿地が継続してきた範囲が 3 カ所認めら れた。ただし，1880 年代に作成された迅速測図において

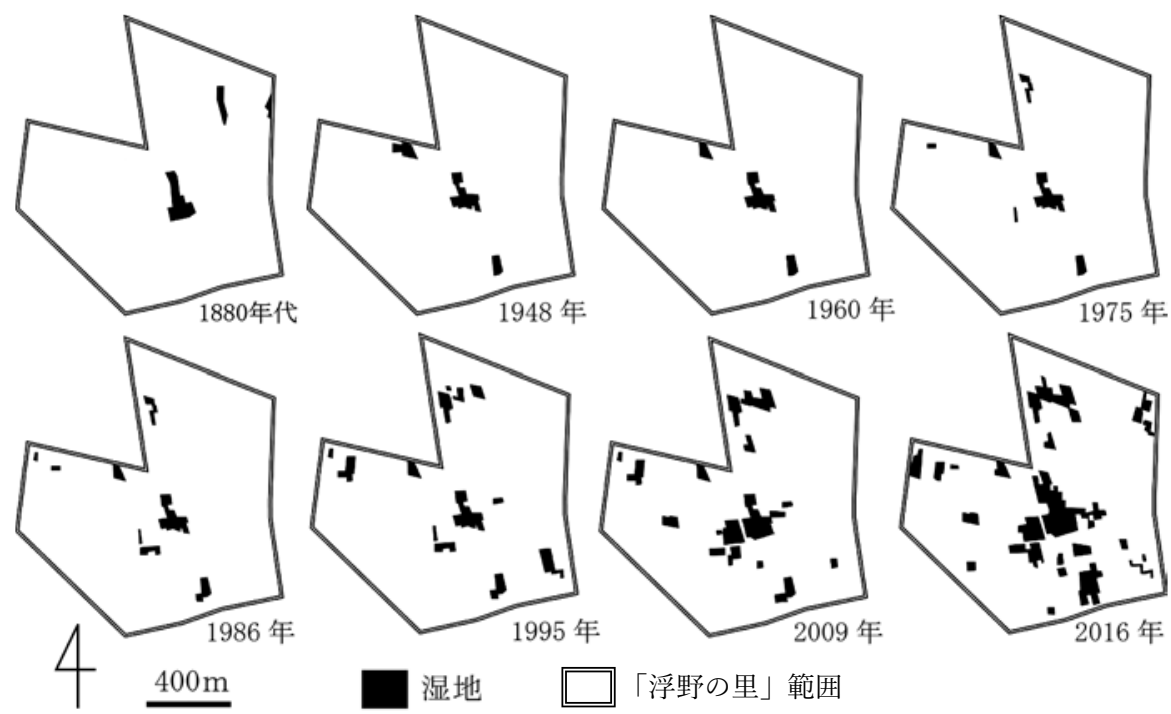

Fig.2「浮野の里」における湿地の変遷 Change of distribution of a marsh in Ukiya no Sato.

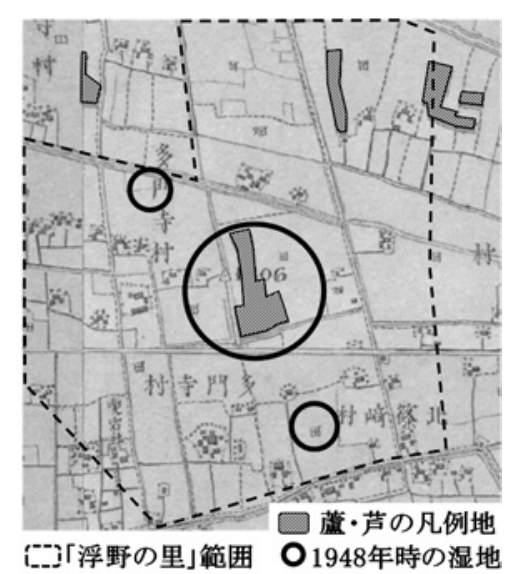

Fig.3 迅速測図（1880～1886 年） ${ }^{12) の ~}$ 湿地分布と 1948 年時の湿地位置 Distribution of a marsh on the oldest map in Japan prepared in Meiji period and arrangement of a marsh in 1948. 
は, その 3 力所の内, 最も規模のある 1 力所（「ちりじ 野」）のみが湿地として記され, 残り 2 力所は「田」の凡 例地であった（Fig.3）。迅速測図では他にも「浮野の里」 の北東部に 2 ケ所湿地が認められたが，1948 年時点では そこは水田となっていた（Fig.2）。

\section{2 「浮野の里」の保全及び葦の会の活動の経緯}

当地区での景観保全活動の契機は, 1952 年に「浮野」 と呼ばれる低湿地（0.5ha, Fig.1 : a ) に関東の平野部では 珍しくトキソウ（Pogonia japonica）やカキツバタ（Iris laevigata）等の北方系の湿生植物が自生していることが 確認されたことによる（1954 年に県天然記念物指定）。

一方, 1980 年代初頭に農業従事者の高齢化や後継者不 足により耕作放棄地が増えつつあった中, 産業廃棄物等 の処理地として埋立て業者の出入りが激しくなったとさ れる ${ }^{13)}$ 。これに危機感を持った地域住民は, 地域の農村 景観や自然環境を守り後世に伝えていくために,「美しい 村づくり委員会」(北篠崎地区住民 50 名で構成) を 1990 年に発足させた。地区の自然環境や景観保全について住 民間での話し合いが持たれ，湿地を活用した活動として 「ちりじ野」でのハナショウブ (I. ensata var. ensata) 等 の湿生園芸花卉類の植栽と花期における「あやめ祭り」 を 1993 年より開始した。

その後, 外部市民との交流も含めた地域活性化に向け, 隣接する多門寺地区住民と共に新たに「浮野の里・葦の 会」を 1997 年に発足させた（「美しい村づくり委員会」 は発展的解散)。北篠崎・多門寺地区の有志 302 名（ほぼ 全世帯) で組織され，会則によると，活動の目的は「郷 土意識を高め, 連帯感を一層深め, 地域の自然環境の保 全・活用と住環境の向上を図り，(中略）...快適で過ごし やすい地域づくりの推進」となっている。

莘の会の現在の年間行事は, 1 月下旬の野焼き, 6 月の 「あやめ祭り」の他, 夏〜秋期に草杊りや清掃活動を行 っている(月 1 回程度) 注1)。中でも湿地景観の保全や病 害虫駆除のために冬季に行うヨシ原の野焼きが, 労力の いる葦の会の重要な活動となっている。先述のとおり, 以前は土地所有者が個別にヨシ原湿地で野焼きを行って いたが，発足後は葦の会が実施主体となり 20 年以上継 続している(現在は市消防部局と連携して実施)。この野 焼き活動等により, 現在「ちりじ野」の湿地一面にノウ ルシ群落が形成され，その開花景観（4 月上中旬）は市 の観光情報誌等に花の見どころとして紹介され, それを 観るために訪れる外部の市民も多い。

当地区での活動におけるシンボル的な自然資源は, 葦 の会の発足当初はトキソウとハナショウブであったとさ れる注1)。特にトキソウについて, 住民の愛好家や行政に
より保護増殖活動が盛んに行われてきた。一方，県卜ラ ストの保全地としての検討が始まる 2000 年頃より,「ち りじ野」等の湿地に自生し, かつ春期に特徵的な開花景 観を呈するノウルシに強く関心が向けられるようになっ たとされる注1)。なお，八ナショウブについては，現在ま で継続して蔁の会のメイン活動の一つ「あやめ祭り」に 活用されている。

現在の葦の会の主な活動場所は, 県天然記念物「浮野」

（Fig.1：a）を除く保全地（同：b・c）である。いずれも 公有地であり, 葦の会は市から保全地の管理委託（野焼 き，草刚り，あやめ園管理等）を受けているが，基本的 にはボランタリーな活動とされる注1)。蔁の会の野焼きの 目的は, 湿地植生の保全が第一で, 他にも美観, 防犯・ 防火とされる注1)。その際, ノウルシが絶滅危惧植物であ るとともに, 地域の湿地を代表する開花景観を呈する植 物であることも認識し ${ }^{13)}$, 野焼きをノウルシの生育環境 保全のための作業とも位置付けているとされる注1)。

なお，保全地の湿地に隣接するクヌギ並木も蔁の会の 草刈り等の活動の場となっている注1)。当地区のクヌギ並 木（延長約 $1,200 \mathrm{~m}$ ) は, かつての薪炭利用のための堤上 の並木の名残とされ注 1), 屋敷林と異なり線状の田堀の水 面と一体化した個性的な景観となっている7)。

\section{3 葦の会会員の意識}

葦の会会員へ 100 枚配布したアンケートの回収数は 69 枚で, 回収率は 69\%であった。属性として, 回答者は男 性が多く $(62 \%)$, 年齢は 60〜70 代が多くなっていた（合 わせて $65 \%)$ 。居住歴は, 当地区で住民活動が始まる時 期すなわち 30 年以上前から住み続けている人が $82 \%$, $30 \sim 20$ 年前, $20 \sim 10$ 年前が各 $4 \%$ で, 大半が新規転入者 ではなくいわゆる地元住民であった。

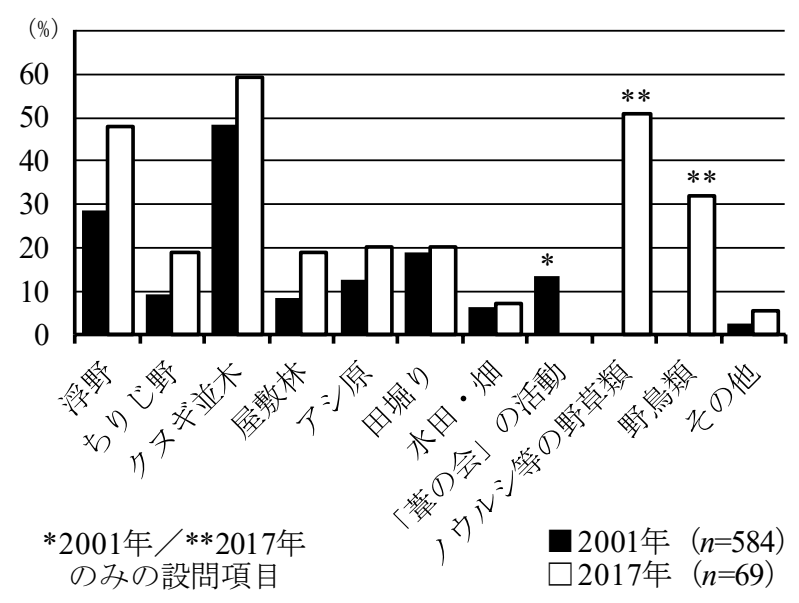

Fig.4「浮野の里」の魅力や美しさについての回答 注 : 2001 年 7の結果も加筆（いずれも複数回答可） Answer about the local attractions of Ukiya no Sato. 
Table 1 「活動におけるやりがい」への回答と「住民の連携」「地域への誇り」「景観保全の認識」のクロス集計 Answer about rewarding in activity and cross tabulation with other consciousness.

\begin{tabular}{|c|c|c|c|c|c|c|c|c|c|c|c|c|c|c|c|c|}
\hline \multirow[b]{2}{*}{ 活動におけ } & \multirow[b]{2}{*}{ ナるやりがい } & \multicolumn{5}{|c|}{ 住民間の連携 } & \multicolumn{5}{|c|}{ 地域の誇り } & \multicolumn{5}{|c|}{ "景観保全の認識 } \\
\hline & & $\begin{array}{c}\text { とても } \\
\text { 強まった }\end{array}$ & 強まった & $\begin{array}{l}\text { どちらとも } \\
\text { いえない }\end{array}$ & $\begin{array}{l}\text { 強まって } \\
\text { いない }\end{array}$ & $\begin{array}{l}\text { 回答 } \\
\text { なし }\end{array}$ & $\begin{array}{l}\text { とても } \\
\text { 強まった }\end{array}$ & 強まった & $\begin{array}{l}\text { どちらとも } \\
\text { いえない }\end{array}$ & $\begin{array}{l}\text { 強まって } \\
\text { いない }\end{array}$ & $\begin{array}{l}\text { 回答 } \\
\text { なし }\end{array}$ & $\begin{array}{l}\text { よくでき } \\
\text { ている }\end{array}$ & $\begin{array}{l}\text { できて } \\
\text { いる } \\
\end{array}$ & $\begin{array}{l}\text { どちらとも } \\
\text { いえない }\end{array}$ & $\begin{array}{l}\text { できて } \\
\text { いない }\end{array}$ & $\begin{array}{l}\text { 回答 } \\
\text { なし } \\
\end{array}$ \\
\hline ある & $19(27.5 \%)$ & 4 & 12 & 2 & 0 & 1 & 2 & 13 & 4 & 0 & 0 & 4 & 13 & 2 & 0 & 0 \\
\hline あまあまある & $41(59.4 \%)$ & 4 & 27 & 10 & 0 & 0 & 3 & 14 & 20 & 1 & 3 & 4 & 30 & 7 & 0 & 0 \\
\hline ない & $6(8.7 \%)$ & 0 & 2 & 3 & 1 & 0 & 0 & 1 & 4 & 1 & 0 & 0 & 1 & 4 & 1 & 0 \\
\hline 回答なし & $3(4.3 \%)$ & 0 & 0 & 1 & 0 & 2 & 0 & 0 & 2 & 0 & 1 & 0 & 0 & 1 & 0 & 2 \\
\hline
\end{tabular}

注:表中数字は回答数。

グッドマン=クラスカルの $\gamma$ 值 $($ 回答なしを除いて算出) : やりがい×住民間の連携 $=0.57$, 同 $\times$ 地域の誇り $=0.60$, 同 $\times$ 景観保全の認識 $=0.60$
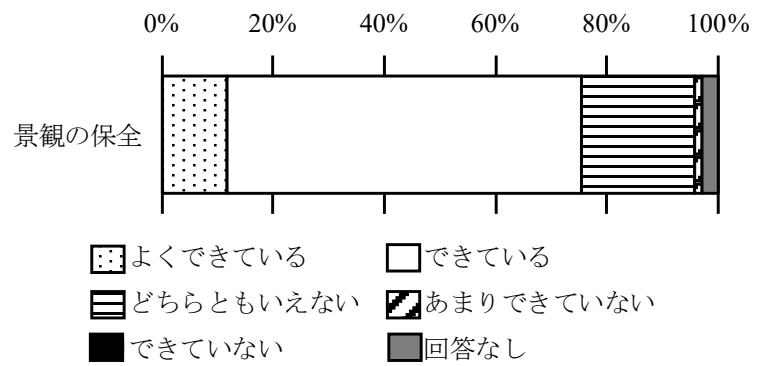

Fig.5 景観保全の認識についての回答 Answer about recognition to the landscape conservation.

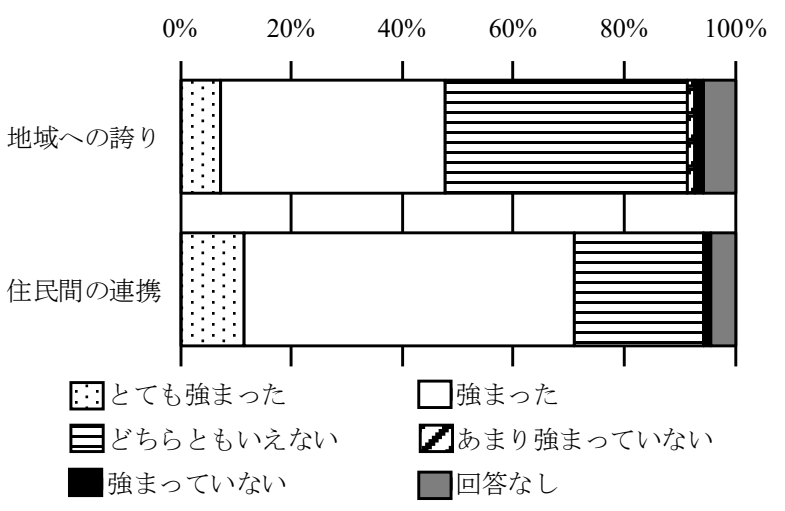

Fig.6 地域への誇り及び住民間の連携についての回答 Answer about pride to their hometown and cooperation between the resident.



Fig.7 当地区の湿地を代表する動植物の認知状況 The recognition situation of the animals and plants which represent a marsh in the target site.
「浮野の里」の魅力や美しさについて（Fig.4）は, 2001 年調査時ではクヌギ並木, 浮野, 田堀り,「蔁の会」の活 動の順に魅力と感じていた7)。2017年の本調査では, ク ヌギ並木 (59\%), ノウルシ等の野草類 $(51 \%)$, 浮野 $(48 \%)$, 野鳥類 (32\%) の順で, 2001 年調査時には項目の無かっ た野草や野鳥類等の野生動植物の生育・生息も高く評価 されていた。また, クヌギ並木と浮野は両調査年時とも 高い值であり，当地区を最も特徵付ける資源であると認 識されていた。

2001 年当時に $83 \%$ (全世带対象) が「景観を保全・活 用し後世へ残したい」と回答していた 7)のに対し，2017 年では活動参加者の $75 \%$ が「浮野の里」の景観維持・保 全状況について「よくできている」「できている」と回答 しており（Fig.5)，自身らの 20 年間もの活動の実績を肯 定的に評価していた。「来訪者が増えることによって地域 の良さを再認識し, 地域への誇りが強まったか（地域へ の誇り)」の問いに対しては「とても強まった」「強まっ た」は $41 \%$ に止まり，「どちらともいえない」(44\%)を やや下回っていた（Fig.6）。また，「活動や寄り合いを通 じて住民間の連携が強まったか (住民間の連携)」の問い に対しては $71 \%$ 「゙「とても強まった」「強まった」と回 答し，蔁の会の活動を通じて住民同士の絆を強めている と多くの人が認識していた。

蔁の会の活動における「やりがい」については，87\% が「ある」「まあまあある」と肯定的な回答であった（Table

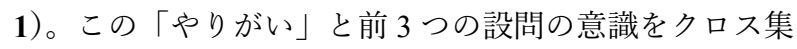
計した結果, いずれも正の相関が認められた（グットマ ン=クラスカルの $\gamma=0.57 \sim 0.60)$ 。すなわち, 活動を通じ て「住民の連携が強まった」ことや「地域への誇りが強 まった」ことを意識している人济ど，さらに活動によっ て「景観保全ができている」と認識している人ほど,「や りがい」を強く感じていた。なお，具体的な「やりがい」 の内容を問う自由回答では, 「環境保全・管理」,「地域住 民とのコミュニケーション・ふれあい」等の意見が得ら れている。

最後に, 当地区の湿地の自然資源として代表的な動植 
物の認知状況を聞いたところ（Fig.7），ノウルシは大半 （91\%）が認知していたが，カヤネズミは 40\%以下に止 まっていた。

\section{4. 考察}

\section{1 湿地の変遷と景観保全活動の展開}

埼玉県の土地分類基本調査 ${ }^{14)}$ によると，加須低地は利 根川・荒川の氾濫原であり, 自然堤防と砂丘が発達し, 後背湿地には各所に湿地が散在分布するとしている。当 地区では，江戸初期から中期にかけて用排水の整備と並 行して新田の開拓が進んだとされる ${ }^{15)}$ 。ただし, 後背湿 地の過湿地となることも多く, 利根川や荒川の中流部の 平野にはかつて本地区と同様の掘上田が多く分布した 10)。そのような中, 戦後直ぐより現在まで湿地として続 いていた 3 力所は (Fig.2), 戦中・戦後直ぐは食糧難によ り可能な限りの耕地確保が進められたにも関わらず湿地 となっていたことを鑑みると, 戦時中以前より耕作不適 地として湿地が維持されてきた場所と考えられる。それ を裏付けるものとして, 『武蔵国郡村誌』11に税地として 芦萱野が記されているのは先述のとおりである。一方, 迅速測図では内 1 カ所のみが記されるが（Fig.3），トキ ソウ等の生育で天然記念物となっている「浮野」(Fig.1 : a）が水田跡地に成立したとは考えられず，当時の測量で は小規模な湿地は図示において略された可能性が強い。

これらの湿地は, かつては萱の採取地として利用され てきたとされ注1), 過湿地における適応的な土地利用であ ったと言える。これに対し黒田 ${ }^{2}$ は, ヨシは人々の一年 の生活のうち農閑期の主要な収入源の一つであったとす る一方, 直接食糧を生み出すものではないため各種の生 業の組合せにおいて中心となる資源ではなかったと指摘 する。例えば八郎潟湖岸では, 共有地であったヨシ原が 明治後期以降に個別利用地に細分される過程の中で，ヨ シよりも収益性の高い水田に転換されたことが報告され る ${ }^{16)}$ 。当地区でも，かつての萱採取の経済性を失う中で 湿地の多くは水田に転換されたものの，1980 年代以降は 耕作者の減少による休耕地も加わって, ひと時これらの 湿地は地域の課題とされるに至っていた。それが現在,

「浮野」「ヨシ原」「ノウルシ等の野草類」等が地域の魅 力とされているよう (Fig.4), 湿地に対する意識が転換し ていた。

そのような意識転換に至るまでには，学術という外か らの視点による一部の湿地（「浮野」）の天然記念物化と その保護に向けた土地の公有地化がまずあった。続いて 住民の内なる思いとして, 耕作放棄地の増加や産業廃棄 物処理地への危機感, 良質な住環境確保に向けた地域連
携の模索等があった中で, 湿地を外部の人が魅力を感じ る地域景観資源と捉えるようになっていったと考えられ る。すなわち，農業的な経済性の低下した湿地（休耕地 も含む）は産業廃棄物処理地等の候補地となりやすく,

「あやめ祭り」等で湿地を活用することで来訪者による チェック機能を求めたとされる注1)。その際, 修景的なハ ナショウブの植栽と地区外に向けた催しとしての「あや め祭り」が, 個人の土地ではなく公有地化された湿地に おいて進められた点が，特定のグループではなく，地区 全体の取り組みとして行われたという意味で重要と考え られる。また, 2001 年調査時ではトキソウの生育地「浮 野」が高い評価を得ている（Fig.4）等, 当初は湿地を代 表するシンボルとしてトキソウに着目していた。ただし， その生育地である「浮野」自体は既に天然記念物として 保護されており，直接的な活動の場とはならなかった注1) むしろ，野焼き等の具体的な活動の場に生育していたノ ウルシを, 活動とリンクするもう一つのシンボルにする 意識が働いたと推察される。事実, 自らの景観保全活動 （野焼きや夏季の草刈り等）がその生育地保全に結びつ くことを認識しており注1), これは葦の会が自ら 2003 年 に策定した地域計画の中で,「ちりじ野に群生している希 少植物ノウルシ保護のためにヨシ原の維持管理活動を行 う」13)と記されていることからも董付けられる。もちろ ん, 野焼き等の主目的は湿地植生の保全であるが，その 湿地植生を特徵付ける植物としてノウルシを一つのシン ボルとして扱っていると言える。

次に，ノウルシを何時からそのような湿地のシンボル 的な植物と認識するようになったかを検討する。まず, 1950 年代に「浮野」が「初夏はノウルシの黄花におおわ れ」17)という報告があるため, 既に当地区の湿地にノウ ルシは普通に生育していたと推察される。ただし，財） 日本ナショナルトラストが 2001 年に行った住民アンケ ート7)には,「浮野の里」の魅力や美しさの設問項目にノ ウルシはなく（Fig.4）, まだ湿地のシンボルとしての認識 は弱かったと判断される。唯一，このアンケートで「一 番多く利用する季節は」の設問に続く「その季節を一番 多く利用する理由は」において,「ノウルシ観賞」が 3 件 （全 228 件の回答中）のみ認められている 7)。一方，葦 の会が策定した地域計画 ${ }^{13)}$ の中には，ノウルシ等の自生 する希少植物の保護活動の展開や交流・観光として 4 月 にノウルシが開花して多くの来訪者が訪れる等が明記さ れており, ノウルシを地域の特徵の一つとして認識して いた。以上より，2000 年代初頭にかけて，特に自ら地域 計画を策定する過程において様々な地域の将来像と課題 が整理される中で，ノウルシに対する認識が定着したと 推察される。 


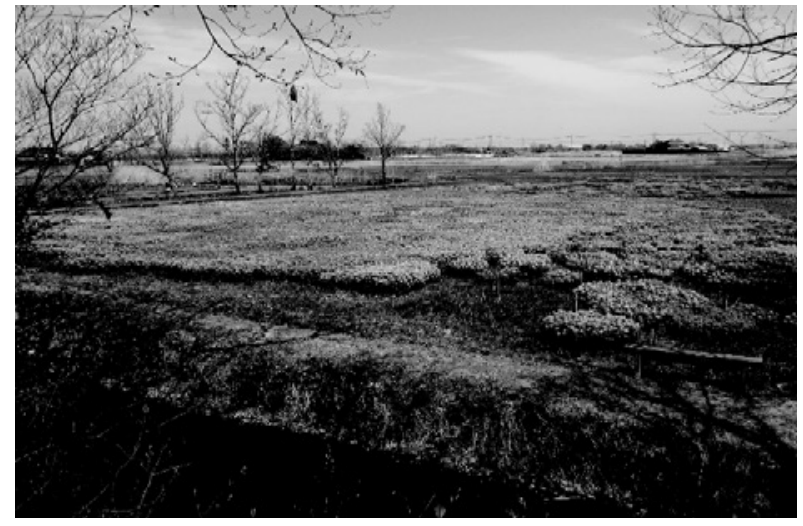

Fig.8 4 月頃に野焼き後の湿地に群生・開花するノウルシ (手前の水路は田堀り)

The flower landscape of Euphorbia Adenochlora in spring in a marsh burned off in Ukiya no Sato.

本地区での野焼きは湿地植生の保全が主目的であった が, その際, 絶滅危惧植物といった希少な湿地生のノウ ルシの生育地となっていること, ノウルシが春先のひと 時に来訪者を呼べる程の壮観な群落開花景観（Fig.8）を 形成すること，が意識されていた。野焼きの中止はリタ 一量の増加や木本種の侵入を引き起こすことが知られて おり ${ }^{18)}$, 野焼きによるリターの焼失は地表付近への日照 確保に繋がると考元られる。実際に一部の湿地生の春型 植物では, 生育地保全に野焼きによる植生管理が有効と

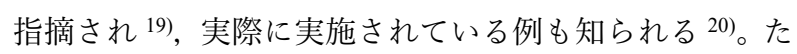
だし，ノウルシに対しては野焼きの継続が生育環境の保 全にどの程度寄与しているかは現時点では不明である。 一方で, 蔁の会が 20 年近く野焼きを継続する中, ノウル シは「昔に比べて大分増えた」注1とされる。重要な点は, 生態学的な効果の有無とは別に, 先述のとおり莘の会入 ンバーが「自分たちが野焼きを継続することでノウルシ の生育地でもある湿地植生が守られている」と認識して いることである。

\section{2 会員の意識と活動継続の関り}

「浮野の里」に感じる美しさや魅力（Fig.4）について， 蔁の会設立初期 (2001 年) と 2017 年時点を比較すると, 全体的に 2017 年の方が各項目の割合が高くなっていた。 それぞれ全世帯（2001 年）と活動参加者（2017 年）と対 象が異なるため割合の違いを単純には比較できないが, 両年とも変わらずに高く評価している地域景観資源の要 素はクヌギ並木と浮野であった。県天然記念物「浮野」 は, 他所には存在しない保護対象の自然として, 現在ま で住民に受け止められていた。これに対し，クヌギ並木 はかつての薪炭利用という, いわば人が育てた緑地要素 である。当地区は平地農業地域であり, 水田等の農地が 広がる中にあって新緑・緑陰・葉の落ちた寒林等の季節
感を醸す雑木からなる並木道が昔から在ること（現在は 散策路として利用）が，身近なそして重要な地域景観資 源として今日まで認識され続けていた。

一方, 2001 年時にはアンケート項目になかったものの, 2017 年では野生動植物の評価も高く, 特に 2017 年では 「ノウルシ等の野草類」は「浮野」よりも若干だが回答 割合は高くなっており, 春期に湿地一面に咲き誇るノウ ルシが地域景観資源として現在高く評価されていた。

活動の評価については, 蔁の会の設立当初から農村景 観の保全・活用は多くの地域住民に望まれていた7,13)。葦 の会設立から 20 年たった 2017 年の時点で, 活動参加者 の多くは自分たちの活動によって景観の保全・活用（会 則の「地域の自然環境の保全・活用」に相当）が出来て いると考元ていることが明らかにされた（Fig.5）。また， 合わせて約 7 割が活動により住民間の連携が強まってい ると考元ており（Fig.6）, 会則の「連帯感を一層強め」は おおむ称達成されていたと判断される。一方, 莘の会は 外部の市民に対して「あやめ祭り」やノウルシの開花景 観の宣伝を行っており, 来訪者が当地区に訪孔ることで 地域景観資源の価值の再認識に繋がることが想定された。 しかしながら，地域への誇りが強まった（会則の「郷土 意識を高め」に相当）と考えている活動参加者は約 4 割 に止まり，地域への誇りを得ることについての成果は限 定的であった。この「地域への誇り」を意識できるため の工夫が課題と言える。

毎年行われる野焼きは, 行政（特に消防部局）との調 整, 事前の刚り払い, 周辺住民一の周知・理解, スタッ フの確保, 本番の火入れといった事務手続きの煩雑さや 多大な現場作業の労力や危険を伴うものであり注1), その 継続には何らかのインセンティブすなわち「やりがい」 が重要となる。本調查では, 会員が活動に参加すること で住民同士のコミュニケーションを通じ地域の連携を図 っている, あるいはあやめ園やノウルシ群落等の地域を 特徵づける景観が外部からの来訪者に注目されることで 地域の価值を再認識して地域に対しての誇りを持つょう になること，が「やりがい」を感じることに関係してい た（Table 1)。農村の地域再生における「地域を誇りに思 う価値観」や「外部からの視点」の重要性は既に指摘さ れているが 21,22), 本事例地のような経済的メリットの低 い景観保全活動のインセンティブにおいてもそれらは極 めて重要な要素と言える。合わせて, 農村の生物相の保 全・回復は, 「誇り」に代表される農村の暮らしの健全性 との連動が求められるとも指摘される ${ }^{23)}$ 。実際, 初夏の 「あやめ祭り」と春先のノウルシの開花景観が観られる 期間は, 当地区に外部の市民が多く訪孔ており，「素敵な 場所ですね」注4) との声を得られる大事な場となっていた 
注1)。これら，景観保全活動によって良質な住環境（住民 間の連携も含む）が持続できるとの認識が，野焼き等の 活動の継続に強く関与していると考えらえた。さらに, 自身らの活動によって湿地の景観すなわち湿地植生が保 全されているという認識が「やりがい」の多寡にも結び ついており（Table 1), 活動の結果が具体的な空間として 目に見える形（本事例では良好な湿地植生を有するヨシ 原）で存在することも活動の持続に強く関与することが 示唆された。

\section{3 自然資源シンボルを用いた景観の管理・保全}

少なくとも明治期より存続した当地区の 3 力所の湿地

（Fig.2, Fig.3）は，戦後の萱材の需要が低下した段階に おいて, 湧水の存在等により土地改良を行っても水田化 が困難な当地区の排水不良な土地条件の下，当時の食料 増産の視点からは地域にとって負の要素であり, それは 過湿地という自然的条件によるものであった。一方でそ れは, 埋没谷からの地下水湧出という地表下の地形や水 文により生じた特性でもあり，天然記念物指定を契機に 湿地を主な舞台とする景観保全活動が進められてきたと いう，地域景観の基盤条件ともなっていた。また，1980 年代以降の水田休耕地の増加（Fig.2）は産業廃棄物等の 処分地の対象になり易いという社会的背景の下，放置で はなく活用が地域課題として持ち上がった。そこで, 湿 地や田堀り，そして湿地に生育するノウルシや植栽した アヤメ類に地域アイデンティティーとしての価值が見出 されてきた。野焼きの主目的はノウルシだけでなく湿地 植生の保全であるが，ノウルシの生育が野焼きといった 地域で続けられてきた伝統的な湿地管理手法と結びつい ていたため, その群落の開花景観を自身らの活動の結果 による地域景観資源と捉えていた。

また，ノウルシについては葦の会会員の多くは当地区 の湿地に生育する植物として認知しており（Fig.7）, また 「浮野の里」の魅力としても高く評価していた（Fig.4）。 これに対し, 希少小動物であり本地区の湿地に比較的高

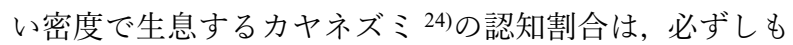
高くはなかった (Fig.7)。ノウルシやハナショウブの開花 景観といった明快なシンボルに対し, 球巣を作るとはい え接触機会の少ないカヤネズミのような小動物をシンボ ルに用いるのは, 現時点では困難と考えられた。野焼き 等の活動が湿地植生の保全のみならず，湿地を利用する 小動物の生息地の保全にも寄与していることを，住民及 び活動参加者が認識する工夫が求められる。

塚本 ${ }^{1)}$ は，これまでのヨシ原の有する生活財・経済的 財に対し, 今日的な環境財としての保全の取り組みが住 民に新たな視点を提供すると指摘する。そこにおいては,
自然資源シンボルが重要な役割を果たすと考えられ，例 えば仏沼湿原では希少鳥類オオセッカ(Locustella pryeri) の生息地を守るという自然保護的価值も野焼きを行う正 当性の一つになっている 3)。当地区の景観保全活動にお ける自然資源シンボルは, 湿地植生あるいはノウルシと いったものであったが，合わせて自ら植栽・管理してい る湿生園芸花卉類ハナショウブ等も当地区の湿地を特徵

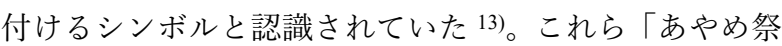
り」やノウルシの開花時の外部来訪者の地域評価（地域 への誇り）も意識しつつ（Fig.6），活動実績を肯定する

（Fig.5）中で住民がやりがいをもって景観保全作業を継 続していた（Table 1)。そこにおいては，単なる景観保全 のための作業に止まらず，コミュニティ醸成の場と認識 していた（Fig.6）ことも，本事例のような住民による景 観保全活動の要諦と言える。

もちろん, 活動参加メンバーの固定化やその高齢化, あるいは混住化に伴う都市的な意識を有する住民の割合 増加といった課題も多い注1)。また，湿地のヨシ原のみな らず，広がる農地，クヌギ並木，屋敷林等も含めて，保 全すべき農村景観と蔁の会は認識しており ${ }^{13)}$, 耕作放棄 地が進む中での他の地域景観資源の保全活用とのバラン スも重要となるだろう。湿地に内在するシンボルになり 得る別の自然資源の発掘あるいはヨシ原以外の地域景観 資源とのつながりの可視化等が，今後の課題である。

謝辞 : 本研究を行うに当たり, 加須市環境政策課及び教育委員 会には，資料提供等の協力を頂いた。また，浮野の里・葦の会 会長（当時）の坪井 敬氏にはヒアリング調査やアンケート調査 を始め，様々な便宜を図って頂いた。この場をかりて，厚く御 礼申し上げます。本研究は科学研究費補助金 基盤研究 C \# 17K08009「景観秩序を活かした農村の生態的・文化的なランド スケープを育む仕組みと実践の研究」（代表者：大澤啓志）の 成果の一部である。

注瀵

注1) 葦の会会長へのヒアリングによる。

注2) ヒアリング対象の会長の属性は, 北篠崎地区在住 (生まれ 育ちも同地区）の 69 歳（2016 年時点）男性で, 莘の会の 発足時 (1997 年)より継続して活動に参画し，中心的な役 割を担っている。莘の会の会長歴は 2013〜2016 年度の 2 期 4 年である。蔁の会による地域計画書『地域おこし計画 「浮野の里」づくり計画』13)作成時において，地域キーパ ーソンからなる「浮野の里」の将来を考える特別委員会」 のメンバーでもあった。

注3）ノウルシは, 環境省レッドリストで準絶滅危惧, 埼玉県レ ッドリストでは絶滅危惧 II 類である ${ }^{25)}$ 。県内では河川敷内 の湿地や湿った所に群生して生育し, 荒川西台地, 大宮台 地，加須・中川低地に広く分布する ${ }^{25)}$ 。

注4) 著者らの現地観察による。

\section{引用文献}

1)塚本善弘（2007）：「コモンズ」としてのヨシ原生態系活用・ 保全の論理・展開・課題一北上川河口域をフィールドとして -, アルテス リベラレス, 81, 179-202. 
2)黒田暁（2009）：生業と半栽培－河口域のヨシ原は何によって 維持されてきた一（宮内泰介編，『半栽培の環境社会学』）。 昭和堂, 京都, 71-93.

3) 竹内健悟・寺林暁良（2010）：多様な価値・目的が生み出す 環境管理の正当性一岩木川下流部ヨシ原における火入れ実施 の課題と 3 事例の比較一, 環境社会学研究, $16,169-178$.

4) 南里美緒・横張真・落合基継（2009）：近江八幡の水郷景観 におけるヨシ原の変遷とその文化的景観としての保全策，ラ ンドスケープ研究, 72(5), 731-734.

5) 曽根真紀・近藤隆二郎（2002）：市民参加型プログラムとし てのヨシ刈りとヨシ松明祭りに関する研究, 環境システム研 究論文集, 30, 183-189.

6)寺林暁良 (2008)：生態系保全における社会的諸条件一の考慮 のあり方一岩木川下流部のヨシ原を事例とした環境史による 提言一, 保全生態学研究, 13(2), 169-177.

7)財）日本ナショナルトラスト（2001）：『ふるさとの原風景 浮谷の里〜市民参加による保全・活用計画』, 東京.

8) 堀口萬吉（1997）：利根川中流低地の変動と古代地震, 地球 科学, 51(1), 40-50.

9) 堀口萬吉（1996）：加須市浮野の地質（加須市教育委員会, 『埼玉県指定「加須の浮野とその植物」調查報告書』）, 加須 市教育委員会, 埼玉，75-83.

10)元木靖（2013）：掘上田再考一関東平野中央部の掘上田景観 に注目して，経済学季報，63(1), 25-61.

11)埼玉県編（1954）：『武蔵国郡村誌』，埼玉県立図書館，埼 玉.

12)農研機構農業環境変動研究センター（参照 2019.4.1）：歴史 的農業環境閲覧システム https://habs.dc.affrc.go.jp/

13)浮野の里・蔁の会 (2003) : 『地域おこし計画「浮野の里」 づくり計画』, 埼玉.

14)埼玉県 (1975)：『利根・県南開発地域 土地分類基礎調査』,
埼玉.

15)加須市郷土史編さん委員会（1969）：『加須市の郷土史』， 加須市, 埼玉.

16)佐野静代（2005）：エコトーンとしての潟湖における伝統的 生業活動と「コモンズ」一近世〜近代の八郎潟の生態系と生 物資源の利用をめぐって一, 国立歴史民俗博物館研究報告, 123, 11-34.

17)橋本庸（1954）：埼玉県加須市東部の浮島の植物相, 採集と 飼育, 16(10)，305-307.

18)山本嘉人 · 進藤和政 - 萩野耕司 - 平野清 - 中西雄二 · 大滝典 雄（2002）：阿蘇地域の半自然草地における火入れ中止にと もなう植生の変化, 日本草地学会誌, 48(5), 416-420.

19)澤田みつ子・小幡和男 -上條隆志・中村徹（2011）：利根川 水系における絶滅危惧種タチスミレの生育立地とその植生管 理, 日本緑化工学会誌, 37(1), 44-49.

20)さいたま市教育委員会（2014）：『国指定特別天然記念物田 島ケ原サクラソウ自生地保存管理計画策定報告書』, 埼玉.

21)結城登美雄 (2009) : 『地元学からの出発』, 農文協, 東京. 22)小田切徳美・藤山浩編 (2013) :『地域再生のフロンティア』, 農文協, 東京.

23)大澤啓志・大久保悟・楠本良延 - 嶺田拓也（2008）：これか らの農村計画における新しい「生物多様性保全」の捉え方, 農村計画学会誌, 27(1), 14-19.

24)黑田綱貴・曽根賢・大澤啓志（2019）：平野部水田域の半自 然草地におけるカヤネズミの営巣習性, ランドスケープ研究, 82(5), 687-690.

25)埼玉県環境部自然環境課（2012）：『埼玉県の希少野生生物 埼玉県レッドデータブック 2011 植物編』, 埼玉.

（2019.5.31 受理，2019.9.13 採用） 